\title{
Feeding ecology of the crab Cancer polyodon in La Herradura Bay, northern Chile. II. Food spectrum and prey consumption
}

\author{
Gerardo Cerda ${ }^{1}$, Matthias Wolff ${ }^{2}$ \\ ${ }^{1}$ Universidad Católica del Norte, Casilla 117, Coquimbo, Chile \\ ${ }^{2}$ Center for Tropical Marine Ecology, Universitätsallee GW 1/A, D-28359 Bremen, Germany
}

\begin{abstract}
Cancer polyodon stomachs were analyzed to determine the dietary breadth and relative importance of prey species of male and female crabs at 2 study sites in La Herradura Bay throughout the year. Of 51 prey items identified, small crustaceans and molluscs of a wide size range predominated at both localities, followed by echinoderms, polychaetes, fish and algae. Cannibalism was high (10\% of total crab production) and showed 2 peaks during winter and summer respectively, indicating recruitment pulses. Significant differences in diet composition were found between sexes, localities, seasons and sizes. Females consumed greater quantities of the deep-burrowing jackknife clam Tagelus dombei than males. Most egg-carrying females were found not to feed. In one of the study areas (characterized by a heterogeneous rocky-sandy bottom covered with algae), cirripeds Austromegabalanus psittacus and porcellanid crabs Petrolisthes spp. were of highest relative importance (6.96 and $6.38 \%$ ), while in the other area (a homogeneous sandy bottom without algae) Tagelus dombei was by far the most important species $(42.2 \%)$ followed by the gastropod Priene rude $(2.82 \%)$. Small crabs $(<8.0 \mathrm{~cm})$ ingested a higher proportion of molluscs at both study sites, while crustaceans had a higher relative importance in stomachs of large crabs $(>11 \mathrm{~cm})$. Echinoderms and fish were absent in stomachs of small crabs ( $<8.0 \mathrm{~cm}$ carapace width). Estimates of annual prey consumption/area are given and the crabs' functional role in the shallow water community of La Herradura Bay is discussed.
\end{abstract}

\section{INTRODUCTION}

The food habits of brachyuran crabs attracted attention in the 1960 s when it became evident that crab predation could heavily influence the abundance and distribution of their prey species, some of which were of commercial value (Elbing et al. 1964, Muntz et al. 1965, Ropes 1968). Typically, brachyuran crabs are generalists feeding primarily on small molluscs and crustaceans of limited mobility (Williams 1981, 1982, Morales \& Antezana 1983, Elner et al. 1985, Haddon \& Wear 1987, Rangeley \& Thomas 1987, Ryer 1987). Ontogenetical changes in the diet spectrum were attributed to anatomical differentiation of the feeding apparatus ('gastric mill') during growth (Hill 1976, Gotshall 1977, Jewett \& Feder 1982, Laughlin 1982, Stevens et al. 1982, Perez \& Bellwood 1988). Differences in diet composition were also found between lo- calities and seasons, and were attributed to differing prey availabilities in each environment.

Cancer polyodon (Poeppig, 1836) is the most conspicuous of the 4 species of the genus Cancer inhabiting the coastal waters of Chile and Peru (Retamal 1981). Males measure up to almost $20 \mathrm{~cm}$ carapace width (CW), while females remain smaller (Garth 1957 , Wolff \& Soto 1992). It has been fished for decades by divers and captured with traps in the Southeast Pacific (Antezana \& Fagetti 1965). Fishing pressure seems to have intensified over the last decade as seen by increased landings (SERNAP 1987, 1988 as cited by Wolff \& Soto 1992). In a study area of La Herradura Bay, Wolff \& Soto (1992) found average crab densities of 0.15 ind. $\mathrm{m}^{-2}$. The present study is designed to determine the food spectrum and relative importance of prey species of both sexes at 2 distinct localities in La Herradura Bay over 1 yr, and to estimate the prey con- 
sumption per area using the results of this and a previous study on feeding periodicity and food consumption (Wolff \& Cerda 1992).

\section{MATERIAL AND METHODS}

Cancer polyodon were collected by hand in monthly intervals over 1 yr (May 1988 to April 1989) at 2 study sites in La Herradura Bay (Fig. 1). The first site, Marina de Guayacán (MG), is characterized by a rocky sandy bottom covered with red and green algae. The second, Guayacán (G), has a more homogeneous sandy bottom almost without algae. At each sampling, about 15 specimens (total number: 340 ) were collected from the water at 1.0 to $10.0 \mathrm{~m}$ depth between 08:00 and 09:00 $\mathrm{h}$ as stomach fullness had been found to be high at this time (Wolff \& Cerda 1992). After collection the specimens were killed by an oral injection of formalin $(10 \%)$ and transferred to the laboratory to sex the crabs, to measure $\mathrm{CW}$ to the nearest $0.1 \mathrm{~mm}$ with a calliper and to record fresh weight to the nearest $0.1 \mathrm{~g}$. Subsequently, the carapace was separated from the abdomen and the stomach was extracted and bled on absorbent paper for 5 min to eliminate excessive liquid. Stomach weight was recorded with and without food, and stomach content was emptied into a petri dish for subsequent analysis.

Stomach fullness and stomach content analysis. Relative stomach fullness (RSF) was defined as in situ stomach fullness $\left(V_{\mathrm{e}}\right)$ divided by the maximum stomach fullness of a crab of the same size $\left(V_{m}\right)$.

$$
\mathrm{RSF}=V_{\mathrm{e}} / V_{\mathrm{m}}
$$

$V_{\mathrm{m}}$ was obtained by the following method described by Hill (1976): empty stomachs of different-sized crabs were filled with seawater and the displacement volume $\left(=V_{\mathrm{m}}\right)$ was measured and correlated with CW (Fig. 2). RSF was then obtained using Eq. 1. The stomach content was analyzed by recording the frequency of occurrence of each food item and by using the point assignment method (Hynes 1950). Following this method, a number of points were assigned to a prey item according to a logarithmic scale (base 2: $1,2,4,8, \ldots)$ as proposed by Williams (1981) and according to the relative stomach fullness recorded.
After analyzing all samples, total fresh weight of each food item $\left(W_{\mathrm{i}}\right)$ was calculated and the following percentages were obtained:

$$
\begin{aligned}
& \% P_{i}=\left(p_{i} / P\right) \times 100(\% \text { points of prey } i) \\
& \% F_{i}=\left(f_{i} / F\right) \times 100(\% \text { of occurrence of prey } i) \\
& \% W_{1}=\left(W_{1} / W\right) \times 100(\% \text { of weight of prey } i)
\end{aligned}
$$

where $p_{1} f_{i}$ and $w_{1}$ are the point, frequency and weight values for each food item and $P, F, W$ are the point, frequency and weight totals of all food items recorded during the analysis. To overcome the bias of the results from the above methods (as discussed by Hyslop 1980, Williams 1981), the following index of relative importance [Zander 1982 (cited by Tarazona et al. 1988)] was used:

$$
M F I=\sqrt{\left(\% p_{i}+f_{i}\right) /\left(2 w_{i}\right)}
$$

where $M F I$ is the index of relative importance and \% $p_{i}, f_{i}$ and $w_{i}$ as explained above. To see if the diet spectrum varied with season and/or crab size, samples

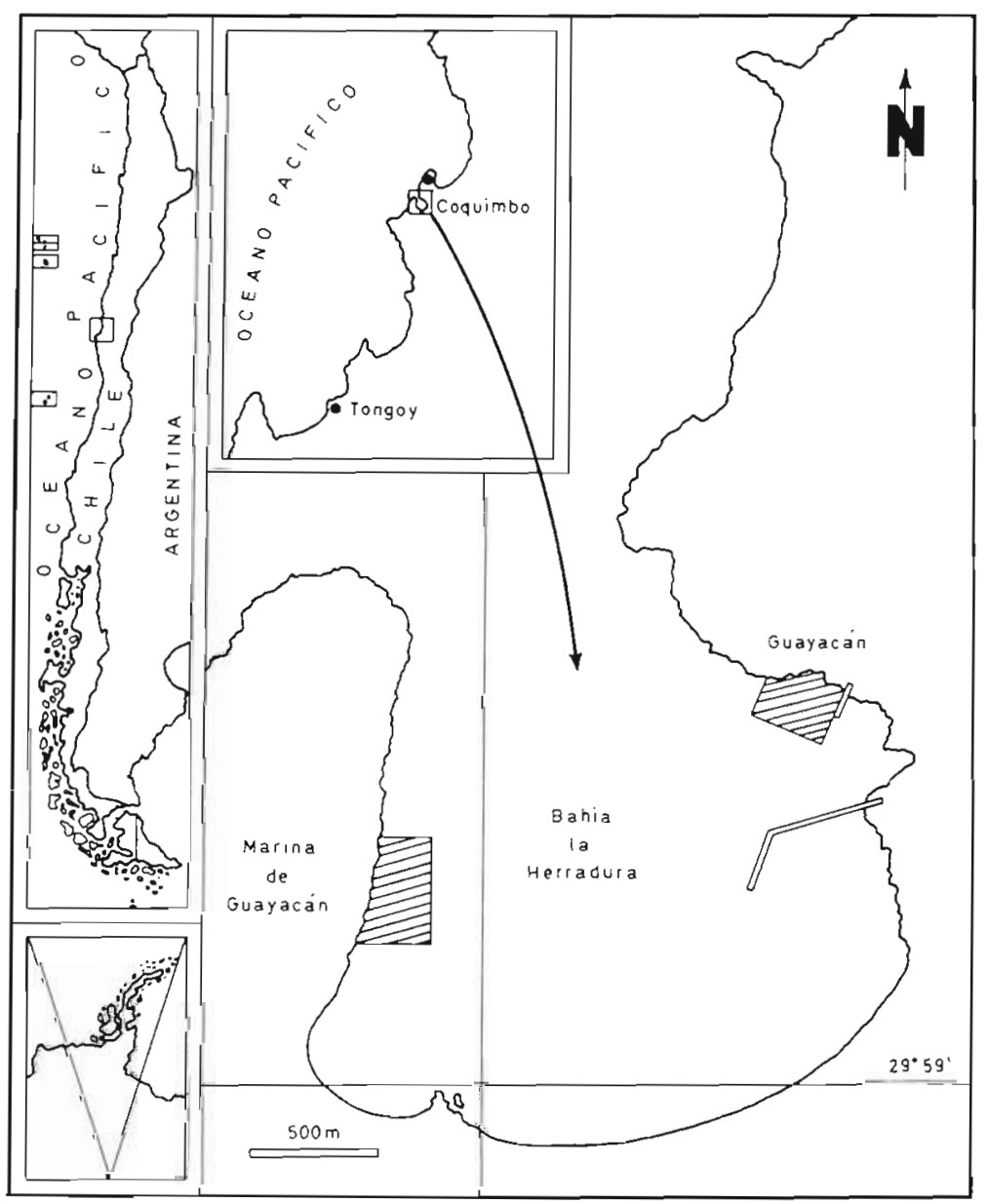

Fig. 1. La Herradura Bay with study sites Marina de Guayacán (MG) and Guayacán (G) 


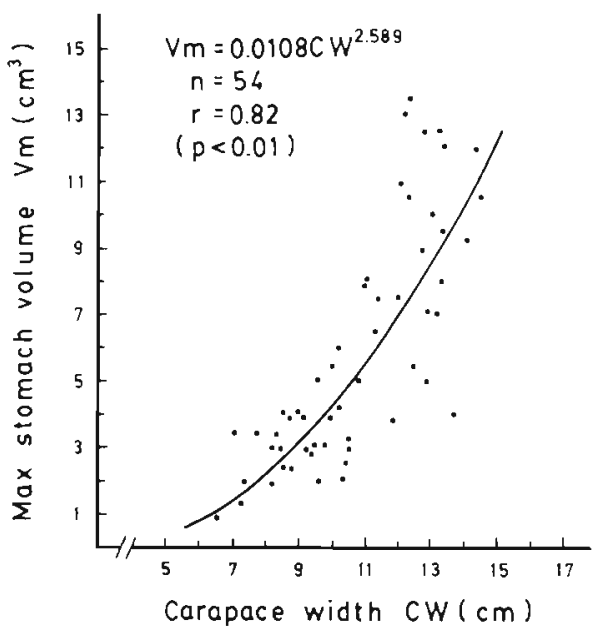

Fig. 2. Cancer polyodon. Relationship between maximum stomach volume $\left(V_{\mathrm{m}}\right)$ and carapace width $(\mathrm{CW})$

were grouped for each season as well as into 3 size groups $(<8.0 \mathrm{~cm}, 8.0$ to $11.0 \mathrm{~cm}$ and $>11.0 \mathrm{~cm} \mathrm{CW})$ for which the $M F I$ values for the different prey species were determined.

Prey consumption. Wolff \& Cerda (1992) estimated an average food intake of $3.19 \%$ body weight (BW) $\mathrm{d}^{-1}$ for crabs of $115 \mathrm{~mm} \mathrm{CW}$ (size representing the population mode) in the Guayacán area. This average and the percentage of total weight of each prey item recorded were then used to quantify the consumption of each prey item $\mathrm{crab}^{-1} \mathrm{yr}^{-1}$. Using the biomass/area estimate of $637 \mathrm{~kg} 5964 \mathrm{~m}^{-2}$ (Wolff \& Soto 1992) we estimated prey consumption on an area basis.

\section{RESULTS}

A higher percentage $(64.8 \%)$ of stomachs analyzed from Site $M G(n=142)$ contained food compared to those from Site G $(58.6 \%, n=203)\left(\chi^{2}=1.08 ; p<0.025\right)$. Average stomach content $(\% \mathrm{BW})$ was very similar between study sites ( 0.49 and 0.48 at Sites MG \& G). Crabs were significantly smaller at Site MG $(8.3 \pm$ $1.9 \mathrm{~cm}$ compared to $10.8 \pm 1.7 \mathrm{~cm}$ at Site G; $t=12.56$, $\mathrm{df}=343 ; \mathrm{p}<0.05)$ with an almost equal proportion of sexes ( 1 male: 1.3 females), while at Site $G$ females dominated significantly ( 1 male: 3.4 females) $\left(x^{2}=\right.$ $5.76 ; \mathrm{p}<0.05)$

\section{Stomach content analysis at both study sites}

Of 51 prey items found in the stomachs of Cancer polyodon, 28 could be identified to species level (Table 1). Organic material and sand (including unidentifiable parts of shells and carapaces) were defined as additional categories. Crustaceans (including $C$.
Table 1 Cancer polyodon. Prey items identified in the stomachs at study sites Marina de Guayacán (MG) and Guayacán (G). MFI: index of relative importance; 'species of highest importance. The proportions of molluscs and crustaceans were significantly different between Sites G \& MG $\left(X^{2}=195.24\right.$; $\mathrm{df}=7 ; \mathrm{p}<0.05$ )

\begin{tabular}{|c|c|c|}
\hline \multirow[t]{2}{*}{ Prey } & \multicolumn{2}{|c|}{ MFI } \\
\hline & $M G$ & G \\
\hline \multicolumn{3}{|l|}{ Crustacea } \\
\hline Crustaced unidentified & 1.51 & 1.42 \\
\hline Isopoda unidentified & 0.20 & - \\
\hline Decapoda unidentified & 9.46 & 3.12 \\
\hline Grapsidae unidentified & 0.55 & - \\
\hline Leptograpsus variogratus & - & 1.13 \\
\hline Paraxanthus barbiger & 0.43 & - \\
\hline Cancer polyodon & $4.91^{\circ}$ & 2.47 \\
\hline Corystoides chilensis & 0.10 & - \\
\hline Pagurus spp. & 0.05 & 0.67 \\
\hline Pagurus edwardsi & 0.50 & 0.92 \\
\hline Pagurus gaudichaudi & 0.56 & $2.54^{\circ}$ \\
\hline Pagurus perlatus & - & 1.51 \\
\hline Petrolisthes sp. & - & 0.11 \\
\hline Petrolisthes desmarestni & $6.38^{\circ}$ & 2.53 \\
\hline Rhynochocinetes typus & 4.20 & 0.09 \\
\hline Synalpheus spinifrons & 0.83 & - \\
\hline Pilumnoides perlatus & 0.12 & 0.14 \\
\hline Talipus sp. & 0.21 & - \\
\hline Eurypanopeus crenatus & 0.42 & - \\
\hline Austromegabalanus psittacus & $6.46^{\circ}$ & 0.45 \\
\hline Caprellidae unidentified & 0.76 & - \\
\hline Total & 37.86 & 17.81 \\
\hline \multicolumn{3}{|l|}{ Echinodermata } \\
\hline Tetrapıgus niger & 0.40 & 0.27 \\
\hline Loxechinus albus & - & 0.09 \\
\hline Total & 0.40 & 0.36 \\
\hline \multicolumn{3}{|l|}{ Polychaeta } \\
\hline Polychaeta unidentified & 0.20 & 0.09 \\
\hline Phragmatopoma sp. & 0.31 & - \\
\hline Total & 0.54 & 0.08 \\
\hline Total fish & 1.96 & 1.70 \\
\hline \multicolumn{3}{|l|}{ Mollusca } \\
\hline Mollusca unidentufied & 0.56 & - \\
\hline Gastropoda unidentified & 0.81 & 2.33 \\
\hline Diloma nigerrima & 0.18 & 0.25 \\
\hline Tegula spp. & 2.79 & 3.93 \\
\hline Turritella cingulatta & 0.48 & 1.85 \\
\hline Prisogaster niger & - & 0.30 \\
\hline Nassarius gayi & 0.09 & - \\
\hline Prene rude & 0.60 & $2.82^{\circ}$ \\
\hline Polyplacophora unidentified & 0.28 & 0.24 \\
\hline Chiton granosus & 2.37 & 1.77 \\
\hline Bivalvia unident. & 4.44 & 1.44 \\
\hline Ennucula grayi & 0.20 & 0.87 \\
\hline Argopecten purpuratus & 1.74 & - \\
\hline Eurhomalea rufa & 0.79 & 0.13 \\
\hline Tagelus dombet & 0.07 & $42.35^{\circ}$ \\
\hline Acmeideae unıdentified & 1.58 & - \\
\hline Garj solida & - & 0.16 \\
\hline Mytilidae unidentified & 0.45 & 0.07 \\
\hline Semimytilus algosus & 0.22 & - \\
\hline Brachidontes granulata & 1.91 & 0.07 \\
\hline Total & 20.13 & 59.41 \\
\hline \multicolumn{3}{|l|}{ Algae } \\
\hline Gracilaria sp. & - & 0.09 \\
\hline Polysiphoniasp. & - & 0.07 \\
\hline Phaeophyta unidentified & - & 0.15 \\
\hline Rhodophyta unidentified & 0.84 & 0.24 \\
\hline Ulva sp. & 7.28 & - \\
\hline Total & 8.32 & 0.62 \\
\hline Organic material & 23.76 & 15.58 \\
\hline Sand & 7.03 & 4.45 \\
\hline
\end{tabular}


polyodon) and molluscs constituted over $50 \%$ (MFI) of the food at both study sites. At Site MG the cirriped Austromegabalanus psittacus and the crab Petrolisthes desmarestii were the most important species (MFI: 6.46 and $6.38 \%$ respectively), while at Site G the jackknife clam Tagelus dombei was by far the most important food item (MFI: $42.35 \%$ ) (Table 1). The size spectrum of the prey ranged from $<1 \mathrm{~mm}$ (in the case of gastropod Ennucula grayi) to several $\mathrm{cm}$ (in the case of T. dombei). At both study sites, algae represented only a small percentage of the stomach content $18.3 \%$ at Site MG, $0.6 \%$ at Site G). Eighty-seven percent of the algal material at Site MG was represented by the green algae Ulva sp. (Table 1), which almost completely filled the stomachs of 2 specimens. At Site MG, crustaceans were consumed in significantly greater quantities than at Site $G$, and molluscs to a greater extent at Site $G$ (Table 1). Among the crustaceans found in the stomachs, C. polyodon constituted the third most important item at Site MG and fifth most important at Site G. Cannibalism peaked between February and April and, more intensively, between August and December (Fig 3). Out of 113 egg-carrying females analyzed, 102 (90.3\%) had empty stomachs.

Differences in diet composition between sexes were found at Site G (Fig. 4) with females consuming a greater proportion of molluscs than males $\left(X^{2}=40.1\right.$; $p<0.01)$. This difference was very pronounced with regard to consumption of the jackknife clam (Tagelus dombei), which constituted $80 \%$ of the molluscs in female stomachs but only $49 \%$ in male stomachs. The proportions of the major taxa in the stomachs collected at different seasons showed significant differences at Sites MG \& G (Table 2). At Site MG crustaceans were of greatest importance in summertime, while at Site $G$ the highest amounts of molluscs were consumed during the same period. Small crabs $(<8 \mathrm{~cm} \mathrm{CW})$ ingested

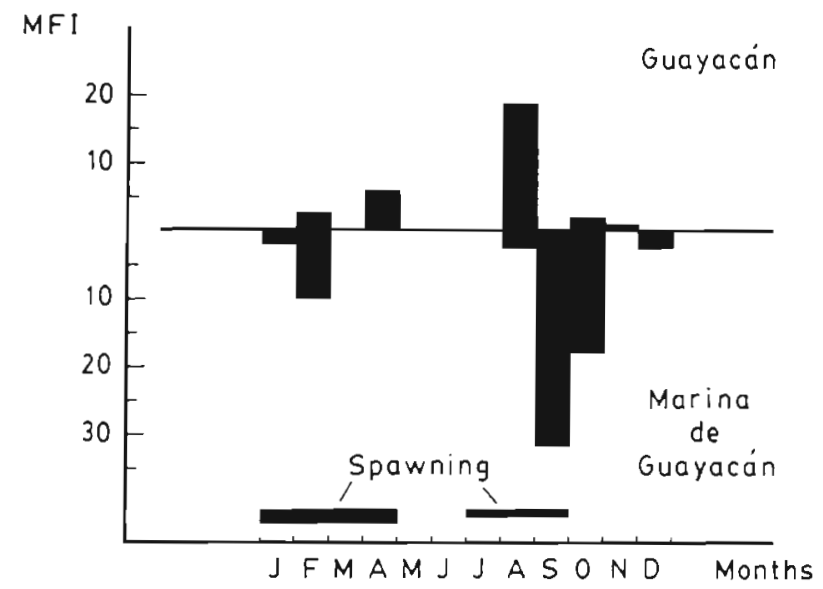

Fig. 3. Cancer polyodon. Cannibalism at Sites $M G$ and $G$ as related to spawning pulses a higher proportion of molluscs, while crustaceans had a higher relative importance in stomachs of larger crabs ( $>11 \mathrm{~cm} \mathrm{CW}$ ). Echinoderms and fish were absent in stomachs of small crabs $(<8 \mathrm{~cm})$ (Table 2$)$.

\section{Prey consumption at Guayacán (Site G)}

Fig. 5 summarizes the consumption of the main prey species by the crab population at Site G together with the population biomass and turnover rate estimated by Wolff \& Soto (1992). Tagelus dombei was by far the most consumed species $(4282.4 \mathrm{~kg} / 637 \mathrm{~kg}$ crab biomass $\mathrm{yr}^{-1}$ or $\left.718 \mathrm{~g} \mathrm{~m}^{-2} \mathrm{yr}^{-1}\right)$.

\section{DISCUSSION}

Our results indicate that Cancer polyodon is essentially carnivorous; only a low percentage of algal material was found in the stomachs. Various authors report that brachyuran crabs accidentally ingest algae (Elner 1981, Laughlin 1982, Stevens et al. 1982, Williams 1982, Perez \& Bellwood 1988) while Hill (1976) found algae to be part of the diet of juveniles. Jewett \& Feder (1982) consider the occurrence of algae in the stomachs as a manifestation of the crabs' opportunistic feeding behaviour. The latter seems to be the case for C. polyodon, as the amount of algae found in the stomachs was significantly higher at Site MG (Table 1), where algae are more abundant, than at Site G

The difference in diet composition between study sites and seasons reflects differences in prey species composition and/or availability. This, and the wide trophic spectrum of 51 food items found, confirms a generalistic and opportunistic feeding behaviour for Cancer polyodon which has been reported for other brachyuran crabs (Hill 1976, Laughlin 1982, Ryer 1987 , Vannini et al. 1989, Hines et al. 1990). This opportunistic feeding behaviour is exemplified by the high relative importance of the clam Tagelus dombei (MFI: $42.35 \%$; see Table 1) in stomachs from Site $G$, where exploratory diving revealed clam densities of up to 130 ind $\mathrm{m}^{-2}$. This bivalve was almost absent at Site MG and in the stomachs of specimens caught there. The high consumption of $T$. dombei indicates the enormous excavating ability of $C$. polyodon, as the clam lives buried in the sand at a sediment depth of 15 to $40 \mathrm{~cm}$. According to Auster \& Crockett (1984), this is characteristic of carnivorous crabs.

The high relative importance of juvenile Cancer polyodon found in the stomachs (MFI. $4.91 \%$ at Site MG and $2.47 \%$ at Site G) indicates considerable cannibalistic behaviour. About $10 \%$ of total crab production. ends up in the stomachs of the crab population (Fig. 5). As cannibalism peaked during the main spawning pe- 


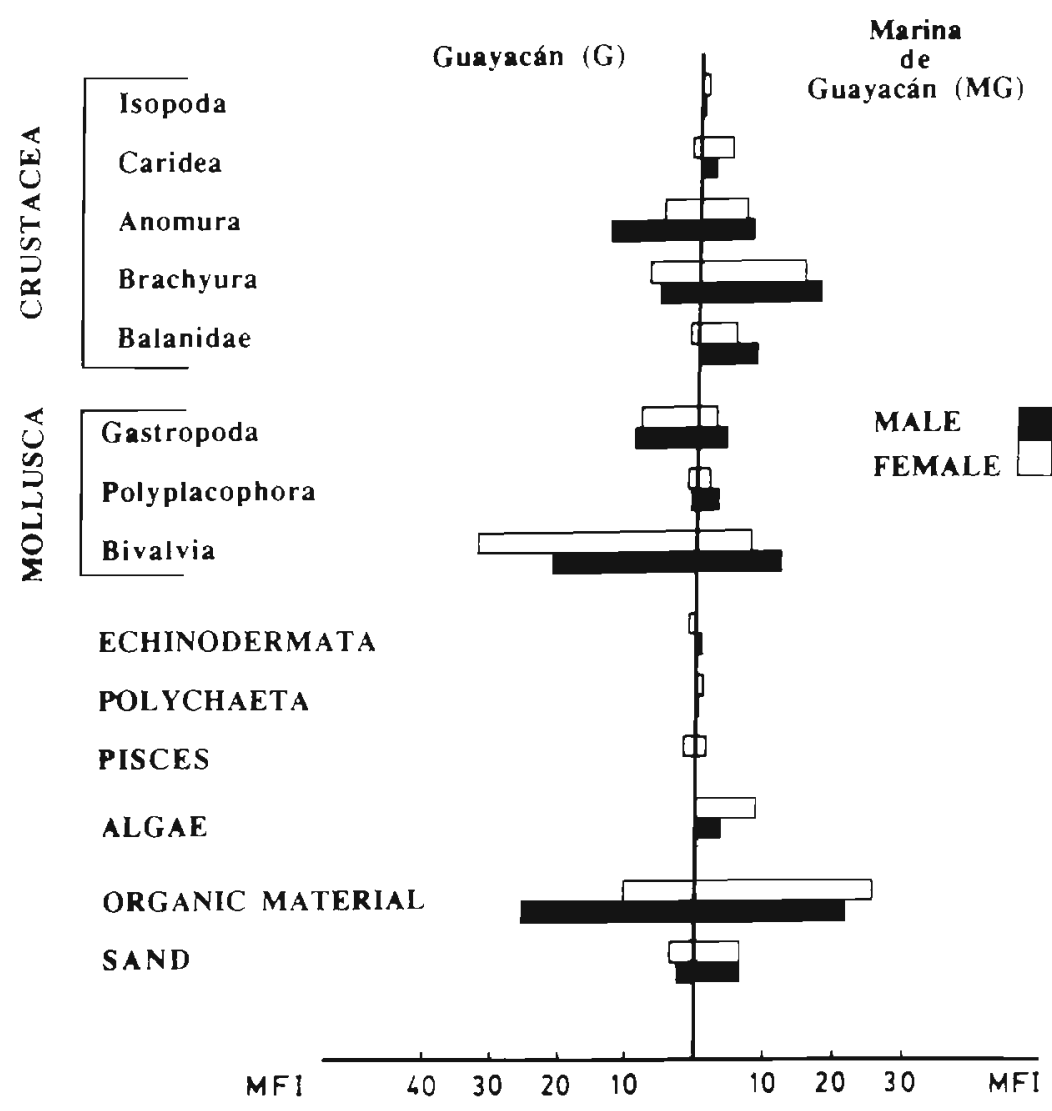

Fig. 4. Cancer polyodon. Index of relative inportance (MFI) ol main food ilerus in male and female stomachs at Sites $M G \& G$, showing females to consume a greater proportion of molluscs than males $\left(x^{2}=40.1, \mathrm{df}=3 ; \mathrm{p}<0.01\right)$ riods in summer (January to April) and winter (July to September) (Fig. 3) (Gutierrez \& Zuñiga 1976, Wolff \& Soto 1992) we assume that most of the juveniles found in the stomachs of the adult population are recruits from the summer and winter spawnings that heavily invade the adult crabs' habitat after ca 6 mo (at 30 to $40 \mathrm{~mm}$ CW). The significantly higher proportion of the mollusc Tagelus dombei in female stomachs at Site G $(80 \%$ compared to $49 \%$ in males), as well as the sex ratio of 1 male to 3-4 females at this site (compared to $1: 1.3$ at Site $M G$ ) suggest that male specimens maintain a 'harem' with several females that they defend within their territory, as also proposed by Orensanz \& Galucci (1988) and Wolff \& Soto (1992). While protecting their harem, males would spend more time at the sediment surface and therefore would more likely prey upon small epibenthic species, like the small crustaceans and molluscs found in their stomachs, rather than on species like $T$. dombei that have to be excavated. The more sedentary females, on the contrary, would be able to excavate prey from the sediment. This hypothesis is substantiated by the fact that at Site
Fig. 5. Cancer polyodon. Diagrammatic representation of trophic relationships between the crab population at Site $G$ and its prey. Numbers on the arrows are in $\mathrm{kg}$; EE: population production efficiency; ZB: annual biomass production $(\mathrm{kg})$; $\mathrm{FI}$ : total annual food intake. $F I$ and $E E$ values from Wolff \& Cerda (1992); ZB values from Wolff \& Soto (1992)

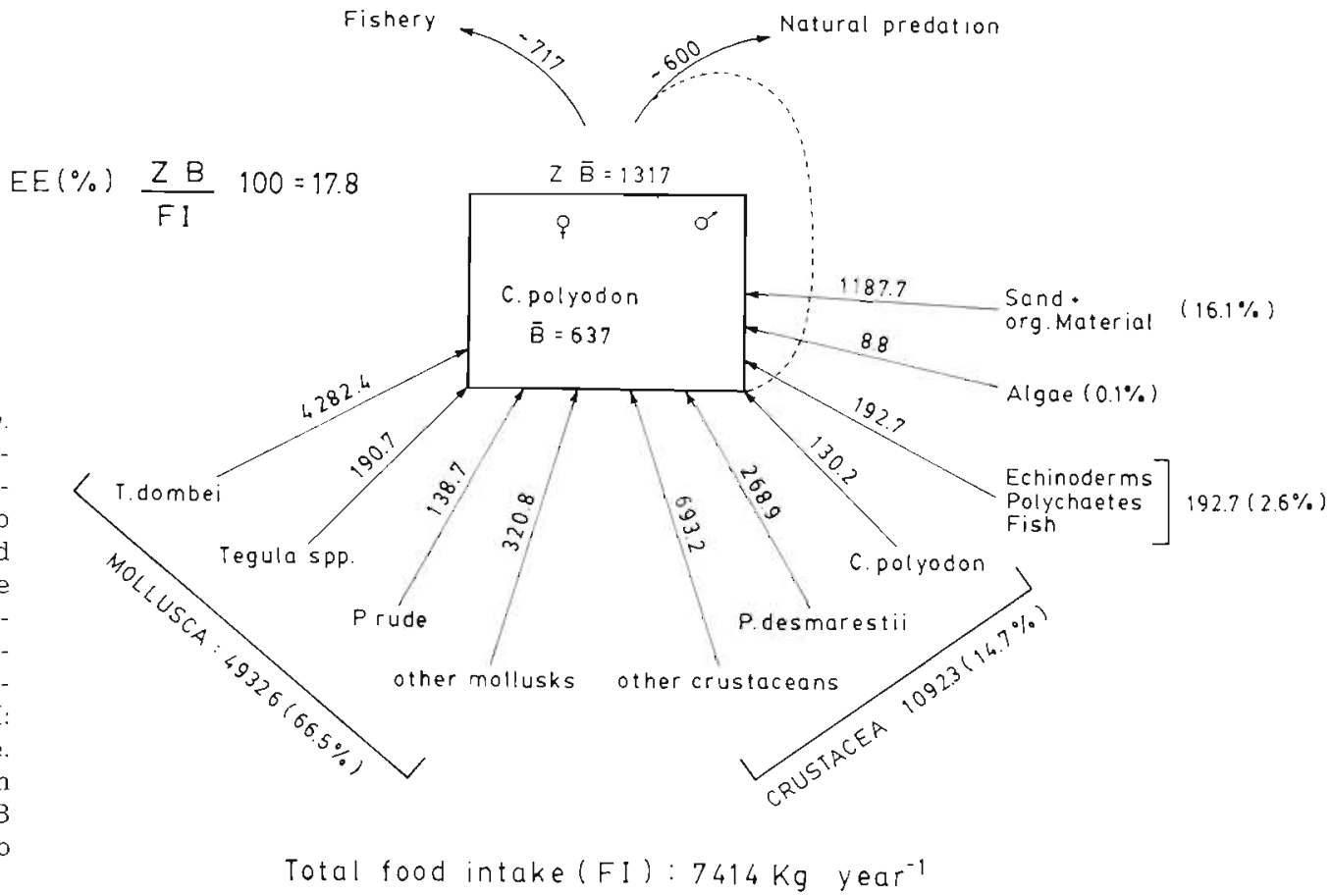


Table 2. Cancer polyodon. Seasonal values and size group specific values of the index of relative importance (MFI) for the main food categories at 2 study sites, Marina de Guayacán (MG) and Guayacán, (G) with contingency table analysis

\begin{tabular}{|c|c|c|c|c|c|c|c|c|c|}
\hline \multirow[t]{3}{*}{ Categories } & \multicolumn{9}{|c|}{ Season } \\
\hline & \multicolumn{2}{|c|}{ Autumn } & \multicolumn{3}{|c|}{ Winter } & \multicolumn{2}{|c|}{ Spring } & \multicolumn{2}{|c|}{ Summer } \\
\hline & $M G$ & G & & $M G$ & $\mathrm{G}$ & $\mathrm{MG}$ & $\mathrm{G}$ & $\mathrm{MG}$ & G \\
\hline Crustacea & 32.7 & 20.2 & & 38.0 & 16.4 & 39.1 & 13.5 & 48.0 & 12.0 \\
\hline Mollusca & 20.5 & 45.4 & & 13.3 & 67.5 & 25.1 & 63.3 & 16.4 & 73.0 \\
\hline Echinodermata & 0.3 & 1.3 & & 0.7 & - & - & -- & - & - \\
\hline Polychaeta & 1.1 & - & & - & - & 0.5 & - & - & 0.2 \\
\hline Pisces & 3.3 & 0.9 & & 0.7 & - & 4.8 & - & - & 4.3 \\
\hline Algae & 2.0 & 0.8 & & 14.6 & 0.6 & 0.8 & - & 12.0 & - \\
\hline Organic material & 31.8 & 28.3 & & 27.2 & 12.6 & 23.0 & 18.3 & 18.0 & 5.5 \\
\hline Sand & 8.2 & 3.1 & & 5.6 & 2.8 & 6.8 & 5.0 & 5.6 & 5.2 \\
\hline \multicolumn{2}{|c|}{ Contingency table analysis: } & $\mathrm{df}$ & & $x^{2}$ & \multicolumn{2}{|c|}{ Cramer's $V$} & $p$ & & \\
\hline & $M G$ & 21 & & 42.14 & \multicolumn{2}{|c|}{0.19} & $<0.004^{\circ}$ & & \\
\hline & $\mathrm{G}$ & 21 & & 43.35 & \multicolumn{2}{|c|}{0.19} & $<0.003$ & & \\
\hline \multirow[t]{3}{*}{ Categories } & \multicolumn{9}{|c|}{ Size groups $(\mathrm{cm})$} \\
\hline & \multicolumn{5}{|c|}{ Marina de Guayacán (MG) } & \multicolumn{4}{|c|}{ Guayacán (G) } \\
\hline & $<8.0$ & & $8.0-11$ & & $>11.0$ & & & $8-11$ & $>11$ \\
\hline Crustacea & 32.8 & & 34.1 & & 50.7 & & & 16.9 & 16.3 \\
\hline Mollusca & 21.8 & & 19.8 & & 9.7 & & .7 & 64.0 & 55.5 \\
\hline Echinodermata & 0.0 & & 0.4 & & 2.0 & & 0 & 0.6 & 0.2 \\
\hline Polychaeta & 0.3 & & 0.6 & & 0.0 & & .0 & 0.1 & 0.0 \\
\hline Pisces & 0.0 & & 2.7 & & 13.3 & & .0 & 0.9 & 1.7 \\
\hline Algae & 7.0 & & 9.6 & & 0.0 & & 0 & 0.3 & 0.2 \\
\hline Organic material & 33.8 & & 25.5 & & 22.3 & & 4 & 13.7 & 20.4 \\
\hline Sand & 4.5 & & 7.4 & & 2.0 & & 4 & 3.3 & 5.7 \\
\hline \multirow[t]{3}{*}{ Contingency table } & sis: & $\mathrm{df}$ & & $x^{2}$ & \multicolumn{2}{|c|}{ Cramer's $V$} & $\mathrm{p}$ & & \\
\hline & $M G$ & 14 & & 46.8 & & & $<0.001^{\circ}$ & & \\
\hline & $G$ & 14 & & 8.7 & & & $<0.85$ ns & & \\
\hline
\end{tabular}

MG, where most crabs were immature and where the sex ratio of $1: 1.3$ indicated the non-existence of harems, no significant sex differences in diet composition was found.

Most egg-carrying females seem not to feed $(90,3 \%$ had empty stomachs), possibly as an adaptation to avoid predation during egg incubation. The extra weight of their large egg clutches would also make them less mobile and more vulnerable to predation.

Smaller crabs ingest a higher proportion of molluscs, while larger crabs a higher proportion of crustaceans (Fig. 5). This and the fact that fish and echinoderms were absent in stomachs of small crabs suggest sizespecific differences in prey accessibility and/or anatomical differences in the feeding apparatus as reported for other crab species le.g. Hill 1976, Gotshall 1977, Jewett \& Feder 1982, Laughlin 1982, Perez \& Bellwood 1988).

As shown in Fig. 5, the Cancer polyodon population at Site G (average biomass: $637 \mathrm{~kg}$ ) consumes annually about 12 times its own biomass $(7414 \mathrm{~kg}$ ). The most preyed-upon species is Tagelus dombei with $4282.4 \mathrm{~kg}$ - followed by the crab Petrolisthes desmarestii, the gastropod Tegula spp. and several other molluscan species. Through cannibalism about $130 \mathrm{~kg}$ of C. polyodon are consumed in the total area, which represent tens of thousands of small juveniles $(<5 \mathrm{~g})$ and about $10 \%$ of total production.

The present and the 2 preceding studies show that Cancer polyodon can be regarded as an extremely efficient converter of benthic production and as a density regulator for most benthic invertebrates due to its large body size, high abundance and biomass, high daily food intake and population production efficiency and its capacity to detect food patches and to aggregate quickly. Its relative abundance in shallow water areas along the Chilean/Peruvian coast may act as an indicator of benthic productivity in these areas. 
Acknowledgements. The study was financially supported by project D.G.I. Universidad Catalica del Norte \# 68.71. Our thanks go to Rachel Wolff, M.Sc., for helping with the English and to 3 anonymous referees whose constructive suggestions helped to improve the manuscript.

\section{LITERATURE CITED}

Antezana, T., Fagetti, E., Lopez, M. T. (1965). Observaciones bioecológicas en Decapodos comunes de Valparaiso. Rev. Biol. mar. 12: 41-60

Auster, P. J., Crockett, L. R. (1984). Foraging tactics of several crustacean species for infaunal prey. J. Shellfish Res. $4(2)$ : 139-143

Elbing, F. J., Kitching, J. A., Muntz, L., Taylor, M. (1964). XIII Experimental observations of the destructions of Mytilus edulis and Nucella lapillus by crabs. J. Anim. Ecol. 33: $73-83$

Elner, R. W. (1981). Diet of green crab Carcinus maenas (L.) from Port Herbert, Southwestern Nova Scotia. J. Shellfish Res. 1(1): 89-94

Elner, R. W., Beninger, P. G., Linkletter, L. E., Lanteigne, S. (1985). Guide to indicator fragments of principal prey. Taxa in the stomachs of wo common Atlantic crab species: Cancer borealis, Stimpson (1859) and Cancer irroratus, Say (1817). Can. Tech. Rep. Fish. Aquat. Sci. 1403

Garth, J. (1959). Reports of the Lund University Chile expedition 1948-1949. The Crustacea Decapoda Brachyura of Chile. Lunds Univ. Arsskr. 53(7): 1-130

Gotshall, D. W. (1977). Stomach contents of Northern Californian Dungeness crabs, Cancer magister. Calif. Fish Game 63(1): 43-51

Gutierrez, M. J., Zúñiga, R. (1976). Cancer setosus Molina en la Bahía de Mejillones del Sur (Crustacea, Decapoda, Brachyura). Rev. Biol, mar. 16(1): 1-25

Haddon, M., Wear, R. G. (1987). Biology of feeding in the New Zealand paddle crab Ovalipis catharus (Crustacea, Portunidae). N.Z. J. of mar. Freshwat. Res. 21: 55-64

Hill, B. J. (1976). Natural food, foregut clearance-rate and activity of the crab Scylla serrata. Mar. Biol. 34: 109-116

Hines, A. H., Haddon, A. M., Wiechert, L. A. (1990). Guild structure and foraging impact of blue crabs and epibenthic fish in a subestuary of Chesapeake Bay. Mar. Ecol. Prog. Ser. 67: 105-126

Hynes, H. B. N. (1950). The food of fresh-water sticklebacks (Gasterosteus aculeatus and Pygosteus pungitius), with a review of methods used in studies of the food of fishes. J. Anim. Ecol. 19: 36-58

Hyslop, E. J. (1980). Stomach contents analysis - a review of methods and their application. J. Fish. Biol. 17: 411-429

Jewett, S. C., Feder, H. M. (1982). Food and feeding habits of the king crab Paralithodes camtschatica near Kodiak Island, Alaska. Mar. Biol. 66: 243-250

Laughlin, R. A. (1982). Feeding habits of the blue crab

This article was presented by J. E. Winter, Valdivia, Chile
Callinectes sapidus Rathburn, in the Apalachicola Estuary, Florida. Bull. mar. Sci. 32(4): 807-822

Morales, C., Antezana, T. (1983). Diet selection of the chilean stone crab Homalaspis plana. Mar. Biol. 77: 79-83

Muntz, L., Elbing, F. J., Kitching, J. A. (1965). The ecology of Lough Ine. XIV. Predatory activity of large crabs. J. Anim. Ecol. 34: 315-329

Orensanz, J. M., Galucci, V.F. (1988). Comparative study of postlarval life-history schedules in four sympatric species of Cancer (Decapoda:Brachyura:Cancridae). J. crust. Biol. Vol. 8(2): 187-220

Perez, O. S., Bellwood, D. R. (1988). Ontogenic changes in the diet of the sandy shore crab Matuta lunaris (Forskal) (Brachyura: Calappidae). Aust. J. mar. Freshwat. Res. 39: 193-199

Rangeley, R. W., Thomas, M. L. H. (1987). Predatory behaviour of the juvenile shore crab Carcinus maenas (L.). J. exp. mar. Biol. Ecol. 108: 191-197

Retamal, M. A. (1981). Catálogo ilustrado de los crustáceos decápodos de Chile. Gayana 44

Ropes, J. W. (1968). The feeding habits of the green crab Carcinus maenas (L.). Fish. Bull. U.S. 67(2): 182-203

Ryer, C. (1987) Temporal patterns of feeding by the blue crab Callinectus sapidus in tidal-marsh creek and adjacent seagrass meadow in the lower Chesapeake Bay. Estuaries 10(2): $136-140$

Stevens, B. G., Armstrong, D. A., Cusimano, R. (1982). Feeding habits of the Dungeness crab Cancer magister as determined by the index of relative importance. Mar. Biol. 72: $135-145$

Tarazona, J., Arntz, W., Hoyos, L. (1988). Repartición de recursos alimenticios entre peces bentófagos frente al Perú antes, durante y después de el Niño 1982-1983. En recursos y dinámica del ecosistema de afloramiento peruano. Tomo I. Boln Inst. Mar Perú. Vol. extraord.: 107-114

Vannini, M., Chelazzi, G., Gherardi, F. (1989). Feeding habits of the pebble crab Eniphia smithi (Crustacea, Brachyura, Menippidae). Mar. Biol. 100: 249-252

Williams, M. J. (1981). Methods for analysis of natural diet in portunid crabs (Crustacea, Decapoda, Portunidae). J. exp. mar. Biol. Ecol. 52: 103-113

Williams, M. J. (1982). Natural food and feeding in the commercial sand crab Portunus pelagicus (L.) (Crustacea, Decapoda, Portunidae) in Moreton Bay, Queensland. J. exp. mar. Biol. Ecol. 59: 165-176

Wolff, M., Cerda, G. (1992). Feeding ecology of the crab Cancer polyodon in La Herradura Bay, northern Chile. I. Feeding chronology, food intake, gross growth and ecological efficiency. Mar. Ecol. Prog. Ser. 89: 213-219

Wolff, M., Soto, M. (1992). Population dynamics of Cancer polyodon in La Herradura Bay, northern Chile. Mar. Ecol. Prog. Ser. 85: 69-81

Zander, C. D. (1982). Feeding ecology of littoral gobiid and blennioid fish of the Banyuls area (Mediterranean Sea). I. Main food and trophic dimension of niche and ecotope. Vie Milieu 32: 1-10

Manuscript first received: February 24, 1992 Revised version accepted: February 22, 1993 